\title{
Perbandingan Jam Kerja Dan Kontribusi Pendapatan Perempuan Dan Laki- Laki Dalam Rumah Tangga Petani Padi Sawah Di Kelurahan Kuranji Kecamatan Kuranji Kota Padang Comparison of Working Hours and Income Contributions of Women and Men in the Households of Rice Paddy Farmers in Kuranji Village, Kuranji Sub-District,
}

\section{Padang City}

Tesya Maryanti Lestari ${ }^{1}$, Mahdi ${ }^{2}$, Lora Triana ${ }^{3}$

\author{
${ }^{1}$ Mahasiswa Program Studi Agribisnis Fakultas Pertanian Universitas Andalas, Padang \\ ${ }^{2}$ Staff Pengajar Program Studi Agribisnis Fakultas Pertanian Universitas Andalas, Padang \\ ${ }^{3}$ Staff Pengajar Program Studi Agribisnis Fakultas Pertanian Universitas Andalas, Padang \\ E-mail Korespondensi: Tesyamaryantilestari@gmail.com
}

\begin{abstract}
Abstrak
Penelitian ini bertujuan untuk (1) Menganalisis perbandingan jam kerja antara laki-laki dan perempuan dalam rumah tangga petani padi sawah, (2) Mengetahui pendapatan rata-rata rumah tangga petani serta kontribusi laki-laki dan perempuan terhadap pendapatan rumah tangga petani (3) Menganalisis hubungan antara jam kerja produktif perempuan dengan pendapatan rumah tangga petani di Kelurahan Kuranji Kecamatan Kuranji Kota Padang. Penelitian ini dilakukan pada tanggal 1 Maret-1 April 2019. Data yang digunakan dalam penelitian ini adalah data primer dan data sekunder. Metode yang digunakan adalah metode survey. Metode pengambilan sampel menggunakan sensus sehingga sampel yang digunakan dalam penelitian berjumlah $66 \mathrm{KK}$. Data dianalisis untuk tujuan pertama dengan perbandingan jam kerja pada kegiatan produktif, reproduktif, sosial budaya yang dicurahkan perempuan dan laki-laki dalam kegiatan tersebut, kemudian terlihat bagaimana waktu senggang yang diperoleh lakilaki dan perempuan. Untuk tujuan kedua melihat berapa kontribusi laki-laki dan perempuan terhadap pendapatan rumah tangganya. Untuk tujuan ketiga analisis ini dilihat dari hasil tujuan pertama dan kedua. Dengan hasil tersebut dapat di lihat total jam kerja produktif perempuan. Apakah jam kerja produktif perempuan memberikan kontribusi pendapatan lebih banyak atau lebih sedikit di bandingkan laki-laki. Hasil analisis menunjukkan bahwa (1) Jumlah jam kerja perempuan lebih tinggi daripada jam kerja laki-laki. (2) Pendapatan rata-rata rumah tangga petani padi sawah adalah Rp. 4.555.745/bulan. Kontribusi pendapatan laki-laki (suami dan anak laki-laki) yaitu 54,42\% sedangkan perempuan (istri dan anak perempuan) yaitu 45,58\%. (3) Waktu yang dikorbankan perempuan untuk kegiatan produktif tidak sebanding dengan pendapatan yang diperolehnya.
\end{abstract}

Kata Kunci: Jam Kerja, Pendapatan, Laki-laki, Perempuan

\section{Abstract}

The aims of this research are to; (1) Analyze the comparison between men and women's working hours in lowland peasant household, (2) Know the average income peasant's family and contribution of men and women to peasant's household income, (3) Analyze the relation between women's working hours and peasant's household income in Kuranji Village, Kuranji District, Padang City. This research conducted on March $1^{\text {st }}-$ April $1^{\text {st }} 2019$. This research utilizes primary and secondary data. The method of this research is the survey. The sampling method is census that uses 66 families. Data analyzed to first purpose by working hour's comparison on productive, reproductive, socio-culture devoted by women and men in these activities and then the leisure time obtained by men and women will be seen. Second purpose is to see how contribution of men and women to their household income. 
Third purpose this analyze is seen from first and second purpose. By that results, can be seen total of women's productive working hours, weather women's productive working hour contributed more or less than men. The final result shows that; (1) Women's Working hour higher than men's, (2) The average income of peasant lowland is Rp4.555.745/month -contribution of men income (men and son) is 54,42\% while women (wife and daughter) is $45,58 \%$, (3) the time that women spent for productive activities is not proportional to the income they earn.

Keywords: Working Hours, Income, Men, Women

\section{PENDAHULUAN}

Pengelolaan usahatani padi, tidak hanya laki-laki saja yang terlibat di dalamnya, tetapi semua anggota keluarga juga ikut berperan, baik istri maupun anak-anaknya. Perempuan di samping bekerja sebagai ibu rumah tangga juga harus bekerja sebagai tenaga kerja pada usahataninya. Fenomena perempuan bekerja telah menjadi hal yang menarik untuk dikaji, lebih-lebih perempuan yang tinggal dipedesaan. Keterlibatan perempuan bekerja sebagian besar disebabkan karena tuntutan ekonomi seperti status ekonomi rumah tangga petani dan luas lahan yang digarap oleh rumah tangga petani sehingga menyebabkan penghasilan rumah tangga petani yang tidak sesuai dengan kebutuhan sehari-hari. Kondisi perekonomian keluarga yang lemah dan serba kekurangan memaksa perempuan ikut bekerja membantu suaminya dalam rangka mendapatkan penghasilan. "Mengingat mayoritas mata pencaharian penduduk desa adalah bertani maka kebanyakan perempuan yang ikut bekerja membantu suaminya pada akhirnya bekerja pula di bidang pertanian" (Komariyah 2003:1).

Kecamatan Kuranji menajdi kecamatan yang rawan mengalami alih fungsi lahan pertanian. Hal tersebut dibuktikan dengan telah menurunnya luas lahan sawah yang ada di Kecamatan Kuranji dalam kurun waktu 23 tahun terakhir. Penurunan yang paling drastis dapat dilihat pada tahun 2014 ke tahun 2015. Luas lahan sawah yang awalnya seluas 2.029 hektar di tahun 2014 menjadi 1.965 hektar pada tahun 2015, hal tersebut berarti telah terjadi pengurangan lahan sawah seluas 64 hektar. Sampai pada tahun 2016 luas lahan sawah masih tetap mengalami penurunan yang cukup besar yaitu seluas 44 hektar dari tahun 2015 ke 2016. Lahan pertanian yang di alih fungsikan sekarang banyak yang telah di jadikan perumahan. Dengan demikian dapat menyebabkan terjadinya perubahan kerja laki-laki ataupun perempuan terhadap usahatani padi maupun pekerjaan di luar usahatani sehingga akan menimbulkan tekanan ekonomi bagi rumah tangga petani. Selain itu Kuranji juga merupakan daerah transisi yang sudah di pengaruhi oleh budaya budaya kota. Karena adanya pertumbuhan jumlah penduduk yang berasal dari luar daerah, sehingga ini juga berdampak bagi kehidupan sosial masyarakat.

Pembagian kerja yang teratur akan berdampak terhadap pendapatan rumah tangga yang maksimum, perlu adanya pembagian peran dalam pekerjaan domestik dan pekerjaan di luar rumah dalam melakukan aktivitas ekonomi. Pembagian kerja antar anggota keluarga tidak saja ditentukan oleh investasi sumber insani dan produksi, tetapi juga oleh gender. Secara biologis, hakekat kaum perempuan tidak hanya berperan dalam fungsi reproduksi saja tetapi juga dalam produksi (Sukarni 1999).

Dalam rumah tangga petani, akses dalam kegiatan produktif (sawah) melibatkan laki-laki dan perempuan sehingga adanya pembagian peran dalam kegiatan produktif. Kegiatan produktif/mencari nafkah dalam rumah tangga untuk pemenuhan pangan rumah tangga di identikkan dengan peran lakilaki. Namun dalam hal ini, kegiatan produktif bukan hanya laki-laki saja yang berperan tetapi perempuan ikut andil dalam kegiatan produktif rumah tangga seperti perempuan ikut berperan dalam pembibitan benih, penanaman, pemeliharaan, panen hingga pasca panen. Lain halnya dengan kegiatan reproduktif dalam rumah tangga petani, kegiatan reproduktif terkait penyediaan makanan dalam rumah tangga biasanya dilakukan oleh perempuan seperti pengadaan bahan makanan, memasak serta kegiatan reproduktif lainnya cendrung dilakukan oleh perempuan sehingga perempuan sangat mendominasi dalam kegiatan reproduktif namun juga berperan aktif dalam kegiatan produktif. Bagaimana perempuan mengalokasikan waktunya agar dapat tetap seimbang dan hasil yang mencapai optimal. Dalam hal ini digambarkan peranan ganda di satu pihak sebagai ibu rumah tangga dan dilain sebagai pencari nafkah. 
Atas dasar itu, maka perlu di adakan penelitian yang bertujuan untuk melihat Perbandingan Jam Kerja Dan Kontribusi Pendapatan Perempuan Dan Laki-Laki Dalam Rumah Tangga Petani Padi Sawah Di Kelurahan Kuranji Kecamatan Kuranji Kota Padang dengan rumusan masalah sebagai berikut :

1. Bagaimana perbandingan jam kerja antara laki-laki dan perempuan dalam rumah tangga petani padi sawah?

2. Berapa pendapatan rata-rata rumah tangga petani serta kontribusi laki-laki dan perempuan terhadap pendapatan rumah tangga petani?

3. Bagaimana hubungan antara jam kerja produktif perempuan dengan pendapatan rumah tangga petani?

\section{METODE PENELITIAN}

Penelitian ini dilakukan di Kelurahan Kuranji Kecamatan Kuranji Kota Padang. Penentuan daerah penelitian dilakukan dengan metode purposive atau sengaja, Metode yang digunakan dalam penelitian ini adalah mentode survey. Metode survey adalah metode yang diadakan untuk memperoleh fakta-fakta dari gejala-gejala yang ada dan mencari keterangan-keterangan secara aktual, baik tentang institusi sosial, ekonomi, atau politik dari suatu kelompok ataupun suatu daerah. Dalam menganalisis data untuk tujuan pertama dengan melihat perbandingan jam kerja wanita dan laki-laki dalam kegiatan produktif, reproduktif, dan sosial budaya. Data yang dianalisis adalah perbandingan jam kerja dalam kedua aktivitas kerja yaitu produktif, reproduktif, sosial budaya yang dicurahkan wanita dan laki-laki dalam kegiatan tersebut, kemudian terlihat bagaimana waktu senggang yang diperoleh laki-laki dan perempuan.

Untuk tujuan kedua, yaitu mengetahui berapa pendapatan usahatani dan non usahatani. Lalu melihat berapa kontribusi laki-laki dan perempuan terhadap pendapatan rumah tangganya.

Pendapatan usahatani adalah perkalian antara produksi yang diperoleh dengan harga jual (Soekartawi, 1995). Penerimaan usahatani dapat dirumuskan sebagai berikut :

$$
\mathrm{TRi}=\mathrm{Yi} \text {. Pyi }
$$

Dimana :

TRi $=$ Penerimaan petani padi $(\mathrm{Rp} / \mathrm{Ha} / \mathrm{MT})$

Yi $=$ Jumlah produksi padi $(\mathrm{Kg} / \mathrm{Ha} / \mathrm{MT})$

Pyi = Harga jual padi $(\mathrm{Rp} / \mathrm{Kg})$

Pendapatan usahatani adalah selisih antara penerimaan dengan biaya yang dibayarkan (tunai) dalam proses produksi. Untuk menghitung pendapatan petani selama satu musim tanam dapat digunakan rumus menurut Soekartiwi (1995), yaitu :

Dimana :

$$
\mathrm{Pd}=\mathrm{TR}-\mathrm{TC}
$$

$\mathrm{Pd}=$ Pendapatan usahatani padi $(\mathrm{Rp} / \mathrm{Ha} / \mathrm{MT})$

$\mathrm{TR}=$ Total penerimaan $(\mathrm{Kg} / \mathrm{Ha} / \mathrm{MT})$

$\mathrm{TC}=$ Total biaya yang dibayarkan $(\mathrm{Rp} / \mathrm{Ha} / \mathrm{MT})$

Analisis yang dilakukan dalam penelitian untuk tujuan kedua tidak hanya pendapatan usahatani saja, namun juga pendapatan dari non usahatani. Lalu menjumlahkan pendapatan yang di terima laki-laki ( suami dan anak laki-laki) dan perempuan (istri dan anak perempuan).

Pendapatan total rumah tangga petani

$\mathrm{YT}=\mathrm{Yi}+\mathrm{Yj}$

Dimana :

YT : Pendapatan total

Yi : Pendapatan yang diterima laki-laki

$\mathrm{Yj}$ : Pendapatan yang diterima perempuan 
Kemudian melihat bagimana kontribusi antara pendapatan yang di peroleh laki-laki maupun perempuan terhadap pendapatan rumah tangga petani. Berapa \% pendapatan yang diperoleh oleh perempuan, begitu juga dengan pendapatan yang di peroleh laki-laki.

Kontribusi pendapatan laki-laki terhadap total pendapatan rumah tangga dihitung dengan cara sebagai berikut :

$\mathrm{K}=\frac{\mathrm{Yi}}{\mathrm{Yt}} \times 100 \%$

Dimana :

$\mathrm{K}:$ Kontribusi pendapatan laki-laki terhadap pendapatan rumah tangga

Yi : Pendapatan yang diterima laki-laki

Yt : Pendapatan total

Kontribusi pendapatan perempuan terhadap total pendapatan rumah tangga dihitung dengan cara sebagai berikut :

$\mathrm{K}=\frac{\mathrm{Yj}}{\mathrm{Yt}} \times 100 \%$

Dimana :

$\mathrm{K}$ : Kontribusi pendapatan perempuan terhadap pendapatan rumah tangga

$\mathrm{Yj}:$ Pendapatan yang diterima perempuan

Yt : Pendapatan total (Nati, 2012)

Analisis yang di lakukan dalam penelitian untuk tujuan ketiga adalah menganalisa bagaimana hubungan antara jam kerja produktif perempuan dengan pendapatan rumah tangga petani. Analisis ini dilihat dari hasil tujuan pertama dan kedua. Dengan hasil tersebut dapat di lihat total jam kerja produktif perempuan. Apakah jam kerja produktif perempuan memberikan kontribusi pendapatan lebih banyak atau lebih sedikit di bandingkan laki-laki.

\section{HASIL DAN PEMBAHASAN}

\section{A. Gambaran Umum Daerah Penelitian}

Kelurahan Kuranji Kecamatan Kuranji Kota Padang terletak di Provinsi Sumatera Barat dan mempunyai luas wilayah $9,07 \mathrm{~km}^{2}$. Penggunaan lahan terbesar yaitu tanah sawah seluas $6.018,00 \mathrm{Ha}$. Jumlah penduduk di Kelurahan Kuranji pada tahun 2017 adalah 34.133 jiwa. Sarana dan prasarana yang tersedia di Kelurahan Kuranji dapat dikatakan cukup memadai. Hal ini terlihat seperti tersedianya sarana pendidikan, sarana kesehatan, sarana pemerintahan, sarana peribadatan, sarana olahraga, sarana perekonomian, sarana pertanian, dan organisasi kemasyarakatan. Ketersediaan sarana dan prasarana ini membantu masyarakat dalam menjalankan aktivitas sehari-hari dan menunjang berbagai kegiatan ekonomi di dalamnya.

\section{B. HASIL DAN PEMBAHASAN PENELITIAN}

A. Perbandingan Jam Kerja antara Laki-laki dan Perempuan dalam Rumah Tangga Petani Padi Sawah

1. Perbandingan Jam Kerja Laki-laki dan Perempuan dalam Kegiatan Produktif

Kegiatan produktif pada rumah tangga petani padi sawah adalah kegiatan yang bertujuan untuk memenuhi kebutuhan hidup dan terdiri dari beberapa tahapan kegiatan. Perbandingan jam kerja yang dilihat dari berapa lama laki-laki dan perempuan melakukan kegiatan produktif dalam melaksanakan setiap tahapan usahatani padinya. Tahapan kegiatan dalam usahatani padi diantaranya yaitu: penyemaian/persemaian, pengolahan lahan, penanaman, pemupukan, penyiangan, pengendalian hama dan penyakit, pengaturan air dan panen. 
Table 1. Perbandingan Jam Kerja Laki-laki dan Perempuan dalam Kegiatan Produktif (pelaksanaan usahatani padi miliknya)

\begin{tabular}{|c|c|c|c|c|c|}
\hline \multirow[t]{2}{*}{ Kegiatan } & \multicolumn{2}{|c|}{ Jumlah tenaga kerja } & \multicolumn{2}{|c|}{$\begin{array}{c}\text { Rata-rata waktu yang } \\
\text { digunakan }\end{array}$} & \multirow[t]{2}{*}{ Jumlah RT } \\
\hline & $\mathrm{L}$ & $\mathrm{P}$ & $\mathrm{L}$ & $\mathrm{P}$ & \\
\hline Persemaian & 51 & 16 & 1,90 & 1,7 & 60 \\
\hline Pengolahan lahan & 59 & 13 & 10,5 & 10,4 & 49 \\
\hline Penanaman & - & 27 & - & 9,7 & 27 \\
\hline Pemupukan & 56 & 16 & 11,1 & 10,4 & 62 \\
\hline Penyiangan & 62 & 18 & 8,8 & 8,6 & 62 \\
\hline Pengendalian HPT & 63 & 24 & 2,2 & 2,4 & 66 \\
\hline Pengaturan air & 53 & 18 & 3,85 & 3,5 & 66 \\
\hline Panen & 67 & 10 & 10,2 & 12,4 & 56 \\
\hline \multicolumn{3}{|c|}{ Jumlah jam kerja permusim tanam (3 bulan) } & 48,5 & 52,36 & \\
\hline \multicolumn{3}{|c|}{ Jumlah jam kerja perbulan } & 16,2 & 20,7 & \\
\hline \multicolumn{3}{|l|}{ Persentase } & $43,9 \%$ & $56,1 \%$ & \\
\hline
\end{tabular}

Keterangan: L= Laki-laki $\mathrm{P}=$ Perempuan

Berdasarkan uraian diatas dapat disimpulkan bahwa perempuan lebih banyak menghabiskar waktu dalam pelaksanaan usahatani padi sawah dibandingkan laki-laki, dimana rata-rata total waktu yan€ dihabiskan perempuan adalah 54,36 jam sedangkan laki-laki yaitu 44,37 jam dalam satu kali musim tanam. Satu kali musim tanam yaitu 3 bulan. Jadi, waktu yang dihabiskan laki-laki dalam mengelole usahataninya sebulan adalah 14,79 jam sedangkan perempuan menghabiskan waktu 17,45 jam perbulan.

Selain kegiatan usahatani, rumah tangga petani juga melakukan kegiatanproduktif lainnya sepertj berjualan, beternak, buruh tani, buruh bangunan, tukang ojek/sopir dan karyawan/PNS. Dapat dilihat padc tabel 10 dan lampiran 6.

Table 2. Perbandingan Jam Kerja Laki-laki dan Perempuan dalam Kegiatan Produktif lainnya

\begin{tabular}{lccc}
\hline & Kaktu yang digunakan (Jam/Bulan) & \\
\cline { 2 - 4 } & $\mathrm{L}$ & $\mathrm{P}$ & Jumlah RT \\
\hline Berjualan & 184,57 & 202,46 & 20 \\
\hline Beternak & 28 & 56 & 2 \\
\hline Buruh tani & 136 & 110,4 & 11 \\
\hline Buruh bangunan & 122,18 & - & 3 \\
\hline Tukang ojek/sopir & 202,67 & - & 14 \\
\hline Karyawan/PNS & 160 & 181,33 & \\
\hline Jumlah jam kerja/bulan & 833,42 & 550,19 & \\
\hline Rata-rata jam kerja/bulan & 138,9 & 137,5 & \\
\hline
\end{tabular}

Keterangan: $\mathrm{L}=$ Laki-laki $\mathrm{P}=$ Perempuan

Berdasarkan hasil wawancara, ada 20 rumah tangga petani yang melakukan kegiatan produkti berjualan, baik itu berjualan di warung, keliling maupun berjualan di pasar tradisional. Berjualar menghabiskan waktu 184,57 jam bagi laki-laki dan 202,46 jam oleh perempuan dalam sebulan. Kegiatar produktif beternak di lakukan oleh 2 rumah tangga. Beternak ayam dan itik petelur tidak membutuhkar waktu yang lama namun dilakukan setiap hari, laki-laki menghabiskan waktu 28jam dalam sebulan atau 1jam perharinya, sedangkan perempuan menghabiskan waktu 56 jam sebulan atau 2 jam perharinya.

\section{Perbandingan Jam Kerja Laki-laki dan Perempuan dalam Kegiatan Reproduktif}

Kegiatan reproduktif merupakan kegiatan yang berhubungan dengan pemeliharaan atau pengembangan sumberdaya manusia yang ada dalam rumah tangga. Kegiatan reproduktif yang dimaksudkan dalam penelitian ini adalah kegiatan yang dilakukan responden dalam lingkup mengatur dan mengurus rumah tangga. Banyak wilayah dengan lingkungan dan kebiasaan yang mengharuskan dan mewajibkan seorang istri untuk mengerjakan pengelolaan rumah tangga. 
Table 3. Perbandingan jam kerja laki-laki dan perempuan dalam kegiatan Reproduktif

\begin{tabular}{lccc}
\multicolumn{1}{c}{ Kegiatan } & \multicolumn{2}{c}{ Waktu yang digunakan (Jam/Bulan) } & Jumlah RT \\
\cline { 2 - 3 } & Laki-laki & Perempuan & 66 \\
\hline Berbelanja ke Pasar & 6 & 27 \\
\hline Mengumpulkan Kayu Bakar & 5,60 & 8 & 66 \\
\hline Memasak & 26,40 & 66 \\
\hline Membersihkan Rumah & 9,20 & 66 \\
\hline Mencuci & 12 & 19,20 & 44 \\
\hline Mengantar Anak Sekolah & 12,80 & 47 \\
\hline Mengawasi Anak Belajar & 23,96 & \\
\hline Total Kegiatan Reproduktif & 17,6 & 105,56 & \\
\hline
\end{tabular}

Pada tabel diatas dapat dilihat bahwa kegiatan reproduktif berbelanja ke pasar dikerjakan sepenuhnya oleh perempuan. Kegiatan berbelanja ke pasar dilakukan 1 kali dalam seminggu, namun jikc bahan makanan tidak cukup dalam seminggu mereka membeli ke warung yang ada disekitar tempa tinggalnya. Untuk berbelanja ke pasar memakan waktu 6 jam perbulan atau sekitar 1,5 jam dalar seminggu.

Seiring berjalannya waktu, zaman semakin berkembang dimana biasanya perempuan memasak menggunakan kayu bakar, sekarang sudah ada kompor minyak ataupun kompor gas. Dari 66 rumar tangga terdapat 27 rumah tangga yang masih tetap menggunakan kayu bakar. Mencari kayu bakar k€ hutan atau disekitar rumah dilakukan oleh laki-laki maupun perempuan sebanyak 2 kali dalam seminggu Waktu yang dihabiskan laki-laki untuk mencari kayu bakar yaitu 5,6 jam dalam sebulan atau 1,4 jam dalam seminggu. Sedangkan perempuan menghabiskan waktu 8 jam dalam sebulan atau 2 jan perminggunya.

Perempuan harus memasak dan menyediakan makanan untuk anggota keluarganya. Memasak dilakukan setiap hari oleh perempuan dengan menghabiskan waktu 0,94 jam perharinya atau 26,40 jam dalam sebulan. Kegiatan membersihkan rumah dilakukan setiap harinya, kegiatan ini juga memakar waktu yaitu 0,32 jam perharinya atau 9,2 jam setiap bulannya. Membersihkan rumah ini biasanya tidak dibantu oleh laki-laki. Kegiatan mencuci pakaian hanya dilakukan oleh perempuan tanpa adanya bantuar laki-laki. Mencuci pakaian dilakukan rata-rata 4 kali dalam seminggu, dengan menghabiskan waktu 0,67 jam setiap kali mencuci atau 19,2 jam dalam sebulan.

Anak-anak petani di Kelurahan Kuranji banyak yang sekolah jauh dari tempat tinggalnya, sehingga harus diantarkan untuk pergi sekolah. Mengantar anak sekolah melibatkan suami dan istri dalan rumah tangga tersebut, laki-laki menghabiskan waktu 12jam dan perempuan 12,80 jam dalam sebular atau 0,4 jam perharinya. Kegiatan mengawasi anak belajar atau membantu mereka dalam mengerjakar pekerjaan sekolahnya. Kegiatan ini memakan waktu 0,33 jam perhari selama 5 kali dalam seminggu atai menghabiskan waktu 23,96 jam dalam sebulan.

3. Perbandingan Jam Kerja Laki-laki dan Perempuan dalam Kegiatan Sosial Budaya

Kegiatan sosial budaya yang dilakukan oleh laki-laki di Kelurahan Kuranji adalah gotong royong. Gotong royong di lakukan ketika ada sesuatu yang harus dikerjakan seperti membuat banda, surau/mushala serta memperbaiki jalan yang rusak. Kegiatan sosial budaya yang dilakukan oleh perempuan di Kelurahan Kuranji ini adalah majelis ta'lim.

Table 4. Perbandingan jam kerja laki-laki dan perempuan dalam kegiatan Sosial Budaya

\begin{tabular}{cr} 
Kegiatan & Waktu yang digunakan (Jam/Bulan) \\
\cline { 2 - 3 } & Laki-laki
\end{tabular}

\begin{tabular}{lcc}
\hline Gotong Royong & 12,6 & - \\
\hline Majelis Ta'lim & - & 12,14 \\
\hline Total jam kegiatan sosial budaya & 12,6 & 12,14 \\
\hline
\end{tabular}

Berdasarkan hasil wawancara, laki-laki melakukan kegiatan gotong royong tidak secara rutin, namun hanya ketika ada yang akan dibuat seperti surau/mushala, banda dan memperbaiki jalan yang 
rusak. Disaat penelitian ini dilakukan, di daerah tersebut sedang membangun surau, masyarakat terutama laki-laki melakukan gotong royong satu kali seminggu, dapat dilihat pada lampiran 8. Kegiatan ini menghabiskan waktu 12,6 jam sebulan atau 3,15 jam setiap minggu. Kegiatan sosial budaya yang dilakukan perempuan yaitu majelis ta'lim. Kegiatan ini dilakukan satu kali dalam seminggu, ada yang hari senin, kamis atau jumat. Kegiatan majelis ta'lim memakan waktu 12,14 jam dalam sebulan atau 3,03 jam setiap minggunya.

Untuk menjawab tujuan pertama, kita membutuhkan total jam kerja yang dilakukan laki-laki dan perempuan dalam rumah tangga petani padi sawah. Lalu melihat perbandingan antara jam kerja laki-laki dan perempuan.

Table 5. Perbandingan jam kerja laki-laki dan perempuan dalam Kegiatan Produktif, Reproduktif dan Sosial Budaya

\begin{tabular}{|c|c|c|c|}
\hline \multirow[t]{2}{*}{$\mathrm{NO}$} & \multirow[t]{2}{*}{ Jenis Kegiatan } & \multicolumn{2}{|c|}{ Waktu yang digunakan (Jam/Bulan) } \\
\hline & & Laki-Laki & Perempuan \\
\hline \multirow[t]{4}{*}{1} & Produktif & & \\
\hline & Usahatani padi sawah & 14,79 & 17,45 \\
\hline & Pekerjaan lainnya & 138,90 & 137,50 \\
\hline & Total kegiatan produktif & 153,69 & 154,95 \\
\hline 2 & Reproduktif & 17,60 & 105,56 \\
\hline 3 & Sosial Budaya & 12,60 & 12,14 \\
\hline \multicolumn{2}{|c|}{ Total seluruh kegiatan (Jam/Bulan) } & 183,89 & 272,65 \\
\hline \multicolumn{2}{|c|}{ Persentase } & $40,3 \%$ & $59,7 \%$ \\
\hline \multicolumn{2}{|c|}{ Perbandingan } & & \\
\hline
\end{tabular}

Total jam kerja yang digunakan laki-laki yaitu 183,89 jam dalam sebulan, sedangkan perempuar menghabiskan waktu 272,65 jam dalam sebulan. Dapat dilihat bahwa perbandingan jam kerja antara laki. laki dan perempuan dalam rumah tangga petani padi sawah yaitu $2: 3$.

\section{Leisure time/waktu senggang}

Waktu luang/waktu senggang merupakan sesuatu yang terbentuk dari berbagai macam kegiatan baik yang sifatnya mendidik atau menghibur. Waktu luang berisikan berbagai macam kegiatan yang manc seseorang akan mengikuti keinginannya sendiri baik untuk beristirahat, menghibur diri sendiri menambah pengetahuannya atau untuk meningkatkan keikutsertaan dalam bermasyarakat setelah ic melepaskan diri dari pekerjaannya, keluarga dan kegiatan sosialnya.

Table 6. Waktu Senggang Laki-laki dan Perempuan dalam Rumah Tangga

\begin{tabular}{lcc}
\hline \multicolumn{1}{c}{ Uraian } & Laki-laki & Perempuan \\
\hline Total Jam/bulan & 208,11 & 119,35 \\
\hline Persentase & $53 \%$ & $30,4 \%$ \\
\hline
\end{tabular}

Laki-laki/suami di Kelurahan Kuranji menghabiskan waktu luangnya dengan duduk di warung dekat tempat tinggalnya, positifnya kegiatan ini dapat menjalin silaturrahmi antar sesama dan dapat bertukar fikiran serta berbagi informasi yang ada. Selain itu, laki-laki menghabiskan waktu luangnya dengan melakukan hobinya seperti berburu dan memancing. Perempuan memanfaatkan waktu luangnya untuk bermain dengan anak, beristirahat dirumah, dan juga berkumpul dengan masyarakat lain untuk saling bertukar informasi. 
B. Pendapatan Rata-Rata Rumah Tangga Petani Serta Kontribusi Laki-Laki Dan Perempuan Terhadap Pendapatan Rumah Tangga

1. Pendapatan rumah tangga petani pada usahatani padi sawah

Pendapatan adalah sejumlah manfaat yang diterima petani berupa uang yang diukur dalam rupiah. Pendapatan rumah tangga petani berasal dari usahatani padi sawah, dan kegiatan produktif lain yang menghasilkan uang seperti berjualan, beternak, buruh tani, buruh bangunan, tukang ojek/sopir dan karyawan/PNS. Pendapatan usahatani tani padi dapat dilihat pada tabel 13 dan (Lampiran 9).

Table 7. Pendapatan Usahatani Padi Sawah di Kelurahan Kuranji

\begin{tabular}{|c|c|c|}
\hline $\mathrm{NO}$ & Uraian & Per Luas Lahan (Rp) \\
\hline 1 & Harga (Rp) & 6.800 \\
\hline 2 & Produksi $(\mathrm{Kg})$ & 926,14 \\
\hline 3 & Penerimaan & 6.297 .752 \\
\hline 4 & Biaya dibayarkan & \\
\hline 1. & Biaya pupuk & 383.651 \\
\hline 2. & Biaya pestisida & 22.500 \\
\hline 3. & TKLK & 947.030 \\
\hline 4. & Sewa alat & 396.212 \\
\hline 5. & Sewa lahan & 275.101 \\
\hline 6. & Pajak lahan & 1.810 \\
\hline Total & & 2.026 .304 \\
\hline Pendi & patan & 4.271 .448 \\
\hline 5 & Biaya diperhitungkan & \\
\hline 1. & Benih & 69.545 \\
\hline 2. & TKDK & 856.969 \\
\hline 3. & Penyusutan & 46.950 \\
\hline 4. & Pajak & 3.189 \\
\hline 5. & Sewa lahan & 1.809 .924 \\
\hline 6. & Bunga modal & 36.097 \\
\hline Total & & 2.822 .674 \\
\hline 6 & Biaya total & 4.848 .978 \\
\hline 7. & Keuntungan & 1.448 .774 \\
\hline
\end{tabular}

Besarnya pendapatan sangat dipengaruhi oleh penerimaan. Pendapatan diperoleh dari penerimaan dikurangi biaya yang dibayarkan. Pendapatan usahatani padi sawah di Kelurahan Kuranji yaitu Rp. 4.271.448 perluas lahan. Pendapatan usahatani padi merupakan pendapatam rumah tangga, karena yang mengerjakan usahatani padi ini melibatkan laki-laki dan perempuan. Pada penelitian ini, akan dihitung berapa kontribusi laki-laki dan perempuan terhadap pendapatan rumah tangga. Pendapatan yang diperoleh akan dibagi sesuai persentase waktu yang dicurahkan oleh laki-laki dan perempuan dalam mengerjakan usahatani tersebut.

$\begin{array}{ll}\text { Pendapatan laki-laki } & =\frac{45,87}{100} \times 4.271 .448=1.959 .313 \\ \text { Pendapatan perempuan } & =\frac{54,13}{100} \times 4.271 .448=2.312 .134\end{array}$


Kegiatan usahatani satu kali musim tanaman yaitu selama 3 bulan. Jadi total yang diperoleh lakilaki dalam sebulannya Rp. 653.104 dan yang diterima perempuan sebesar Rp. 770.711 dalam sebulan.

\section{Pendapatan rumah tangga petani dari non pertanian}

Anggota keluarga lainnya baik laki-laki maupun perempuan tidak hanya bekerja sebagai petani yang mengelola usahataninya sendiri, namun juga ada yang menjadi buruh tani atau bekerja di lahan orang lain, berjualan, beternak, buruh bangunan, tukang ojek/sopir, karyawan/PNS.

Table 8. Pendapatan laki-laki dan perempuan dari non pertanian

\begin{tabular}{lcc}
\hline \multirow{2}{*}{ Jenis Pekerjaan } & \multicolumn{2}{c}{ Pendapatan perbulan (Rp) } \\
\cline { 2 - 3 } & & Laki-laki \\
\hline Berjualan & 2.577 .143 & 1.726 .154 \\
\hline Beternak & 504.000 & 560.000 \\
\hline Buruh tani & 2.040 .000 & 1.104 .000 \\
\hline Buruh bangunan & 1.880 .000 & - \\
\hline Tukang ojek/sopir & 1.526 .667 & - \\
\hline Karyawan/PNS & 2.468 .181 & 1.833 .333 \\
\hline Jumlah & 10.995 .991 & 5.223 .487 \\
\hline Rata-rata & 1.825 .999 & 1.305 .871 \\
\hline
\end{tabular}

Pendapatan dari anggota keluarga lainnya yang bermata pencaharian sebagai pedagang, mereka berjualan di rumah, keliling bahkan di pasar. Pendapatan laki-laki dalam berjualan ini menghasilkan sebesar Rp. 2.577.143, sedangkan perempuan menghasilkan uang sebesar Rp. 1.726.154. Rata-rata pendapatan yang diperoleh laki-laki yang bekerja diluar sektor pertanian dalam satu bulan adalah Rp. 1.825.999 dan rata-rata pendapatan perempuan adalah sebesar Rp. 1.305.871/bulan.

Total pendapatan yang diperoleh laki-laki dalam rumah tangga petani sebesar Rp. 2.479.103/bulan dan pendapatan yang diperoleh perempuan dalam rumah tangga petani sebesar Rp. 2.076.642/bulan.

Pendapatan total rumah tangga petani pada bulan Februari 2019 adalah

$$
\begin{aligned}
\mathrm{YT} & =\mathrm{Yi}+\mathrm{Yj} \\
& =2.479 .103+2.076 .642 \\
& =4.555 .745
\end{aligned}
$$

Rata-rata total pendapatan rumah tangga petani yang didapatkan sebesar Rp. 4.555.745/bulan.

3. Kontribusi pendapatan laki-laki dan perempuan terhadap pendapatan rumah tangga petani

Kontribusi pendapatan laki-laki adalah persentase sumbangan pendapatan yang diperoleh terhadap pendapatan total rumah tangga yang dihitung dalam satu bulan.

Kontribusi pendapatan laki-laki terhadap total pendapatan rumah tangga dihitung dengan cara sebagai berikut :

$$
\begin{aligned}
\mathrm{K} & =\frac{2.479 .103}{4.555 .745} \times 100 \% \\
& =54,42 \%
\end{aligned}
$$

Kontribusi pendapatan perempuan terhadap total pendapatan rumah tangga dihitung dengan cara sebagai berikut :

$$
\begin{aligned}
\mathrm{K} & =\frac{2.076 .642}{4.555 .745} \times 100 \% \\
& =45,58 \%
\end{aligned}
$$

Kontribusi pendapatan laki-laki sebesar 54,42\% sedangkan kontribusi pendapatan perempuan sebesar $45,48 \%$ terhadap pendapatan rumah tangga. 
Komtribusi pendapatan perempuan dalam rumah tangga petani berada pada status sedang (nilai kontribusi yang didapatkan $\geq 35 \%$ - $\leq 69,9 \%$ ). Artinya adalah bahwa pendapatan perempuan sangat membantu dalam memenuhi kebutuhan keluarganya.

\section{Hubungan antara jam kerja produktif perempuan dengan pendapatan rumah tangga petani}

Total jam kerja produktif perempuan dalam rumah tangga petani adalah sebesar 154,95 jam dalam sebulan, ini lebih besar dibandingkan jam kerja produktif laki-laki yaitu 153,69 jam dalam sebulan. Namun, pendapatan yang dihasilkan perempuan lebih sedikit dibandingkan laki-laki. Kontribusi pendapatan yang dihasilkan perempuan terhadap pendapatan rumah tangga sebesar 45,58\%. Meskipun persentasenya menunjukkan berada pada tingkat sedang, namun pendapatan yang diperoleh perempuan tidak sebanding dengan jam kerja yang telah dikorbankannya. Upah yang diterima perempuan jauh berbeda dengan laki-laki. Contohnya saja dibidang pertanian, sebagai buruh tani laki-laki diberi upah Rp. 120.000 sehari sedangkan perempuan hanya diberi upah Rp. 80.000 dengan jam kerja yang sama yaitu 8 jam sehari.

\section{PENUTUP}

\section{A. Kesimpulan}

Berdasarkan penelitian diperoleh kesimpulan, Kegiatan yang dilakukan laki-laki dan perempuan dalam rumah tangga petani padi sawah yaitu kegiatan produktif, kegiatan reproduktif dan sosial budaya. Total jam kerja laki-laki 182,89 jam dalam sebulan dan perempuan 272,51 jam dalam sebulan atau $2: 3$. Jumlah jam kerja perempuan lebih tinggi daripada jam kerja laki-laki. Pendapatan rata-rata rumah tangga petani padi sawah adalah Rp. 4.555.745/bulan. Kontribusi pendapatan laki-laki (suami dan anak laki-laki) yaitu 54,42\% sedangkan perempuan (istri dan anak perempuan) yaitu 45,58\%. Kontribusi pendapatan perempuan terhadap pendapatan rumah tangga petani tergolong sedang, sehingga dapat membantu perkonomian rumah tangga.Waktu yang dikorbankan perempuan untuk kegiatan produktif tidak sebanding dengan pendapatan yang diperolehnya. Waktu yang dihabiskan perempuan lebih banyak dibandingkan laki-laki namun upah yang diterima perempuan lebih sedikit.

\section{B. Saran}

Dengan melihat jam kerja yang dicurahkan perempuan lebih besar, diperlukan adanya penyadaran masyarakat tentang kesetaraan gender dengan melibatkan laki-laki dalam kegiatan reproduktif. Sebaiknya rumah tangga petani padi sawah lebih memberdayakan tenaga kerja dalam kelurga untuk mengelola usahatani agar pendapatan rumah tangga juga meningkat.

\section{DAFTAR PUSTAKA}

Komariyah. 2003. Profil Wanita Buruh Tani Dalam Usaha Meningkatkan Kesehatan, Desa Wonorejo, Kecamatan Srengat, Kabupaten Blitar. ITB. Bandung.

Kuranji Dalam Angka 1994-2017. Luas Lahan Sawah di Kecamatan Kuranji. Padang : Badan Pusat Statistik

Nati, Nidia Nindi. 2012. Alokasi Waktu dan Peran Pendapatan Wanita Penyiang Lahan Gambir

Dalam Pendapatan Keluarga di Kenagarian Talang, Matur Kecamatan Mungka Kabupaten Lima Puluh Kota..Skripsi Fakultas Pertanian Unand. Padang

Soekartawi, 1995. Analisis Usahatani. Universitas Indonesia Press. Jakarta

Sugiyono. 2011. Metode Penelitian Kuantitatif Kualitatif dan R\&D. Bandung : Alfabeta 